\section{Myötätunto vahvistaa yhteisöjä}

Pessi, Anne Birgitta, Martela, Frank \& Paakkanen, Miia (toim.)

(2017). Myötätunnon mullistava voima. PS-Kustannus. 317 sivua.

MYÖTÄTUNNON MULLISTAVA voima on teos ihmisyydestä, inhimillisyydestä ja yhteydestä ympäristöömme. Se kertoo myötätunnosta, joka on keskeinen osa ihmisyyttä sekä toiset huomioivasta käyttäytymisestä ja sen vaikutuksesta omaan hyvinvointiimme.

Kirjoittajat kuvaavat myötätunnon merkitystä työorganisaatioissa sekä työpaikkojen ulkopuolella ja esittelevät tuloksia CoPassion-tutkimushankkeesta, jota on johtanut kirkkososiologian professori Anne Birgitta Pessi Helsingin yliopistosta.

Teemaa peilataan psykologian ja organisaatiopsykologian tutkimuksiin, antiikin filosofioihin ja uskontoihin mutta myös arkisiin tekoihin. Kirjoittajat antavat käytännön vinkkejä, kuten miten osoittaa myötätuntoa niille, jotka tuntuvat erilaisilta. Myötätuntoa kuvataan erityisesti työelämän näkökulmasta mutta myös terveyden, luovuuden ja merkityksellisen elämän kannalta. Tutkijoiden kehittämä 'myötäinto' kuvaa työyhteisöissä esiintyvää, innostuneisuutta ruokkivaa ilmiötä ja yhdessä tekemisen tunnetta.

\section{MYÖTÄTUNNON ELEMENTIT}

CoPassion-tutkimusryhmän määritelmät myötätunnosta ja myötäinnosta muodostuvat kolmesta elementistä: kyvystä huomata toisen tunnetila, kyvystä eläytyä siihen ja teoista, joilla myötäelämistä ilmaistaan. Kirjoittajien mukaan myötätuntoon kuuluvat empatia ja toisen parasta tavoittelevat teot. Sitä voidaan pitää hyvän yhteiskunnan rakennusaineena, jossa muita ei pidetä uhkana omalle turvallisuudelle tai oikeuksien toteutumiselle.

Myötätuntoon kuuluvat empatian lisäksi toisen parasta tavoittelevat teot. Myötätunto ja myötäinto ovat samanlaisia tiloja - toisen tunteissa mukana elämistä ja mukana elämisen osoittamista teoin. Keskinäinen hyväntahtoisuus sekä ilojen ja surujen jakaminen muiden kanssa ovat tärkeitä niin yksilön kuin yhteisön hyvinvoinnille. Toimiva demokratia edellyttää, että ihmiset välittävät toisistaan ja ovat valmiita puolustamaan demokratiaa, vaikka se ei olisi heidän oman välittömän etunsa mukaista. Myötätuntoinen suhtautuminen auttaa huomaamaan epäoikeudenmukaisuutta yhteisössä ja toimimaan niiden torjumiseksi.

Myötätunnon merkitystä työelämässä ja työpaikoilla kuvataan monipuolisesti teoksessa, ja hyvä niin, sillä myötätunnon kokemus vaikuttaa työssä viihtymiseen, työhyvinvointiin ja työyhteisön tuloksellisuuteen. Myötätunto vahvistaa työyhteisöjen ilmapiiriä ja päätöksentekokykyä. Se motivoi

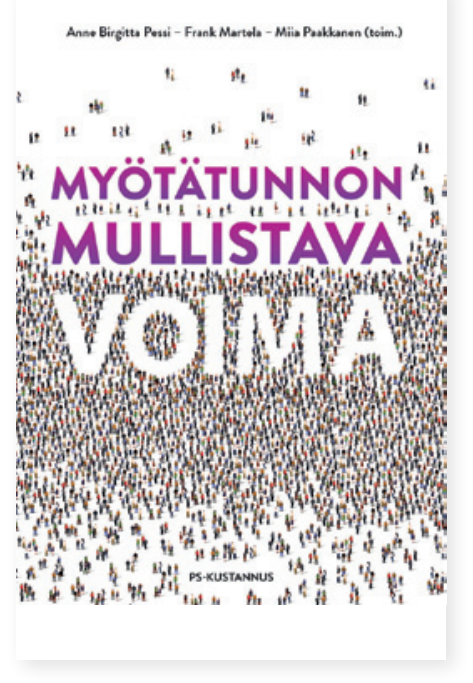

ideoimaan ja luo työyhteisöön psykologista turvallisuutta, joka mahdollistaa uuden oppimisen.

\section{MERKITYKSELLISYYDEN MERKITYS}

Työn merkityksellisyyden kokemusten vaikutukset niin inhimillisessä kuin taloudellisessa mielessä tunnetaan aiempaa paremmin. Työn merkityksellisyydellä tarkoitetaan työntekijän kokemusta oman työnsä arvosta ja siitä, kuinka yhteiskunnallisesti arvokkaan työn osa oma työtehtävä on. Yhdessä tekeminen vaikuttaa työn merkityksellisyyteen. Lisäksi siihen vaikuttavat autonomisuus ja mahdollisuus ilmaista itseä työssä. Myötätuntoinen käyttäytyminen on tutkitusti yksi tehokkaimpia keinoja vahvistaa merkityksellisyyttä.

Miten sitten etätyöskentely ja pirstaloitunut työelämä vaikuttavat myötätunnon, myötäinnon ja turvallisen työyhteisön kokemi- 


\section{TyÖNTEON YTIMESSÄ ON}

\section{HALU EDIST $\dddot{A} \ddot{A}$ TOISEN HYVÄ̈̈.}

seen? Lukukokemus herätti miettimään, minkälaisia digitaalisia keinoja liikkuvaa työtä tekevän tulisi harjoitella yhdessä kollegojensa kanssa: lähikollegan tunnetiloja on hankala lukea etäyhteydellä.

Johtamisen kannalta korostuu ymmärrys siitä, milloin työ ei tuota tekijälleen merkityksellisyyttä tai millaiset elementit estävät merkityksellisyyden kokemisen. Entä onko merkityksellinen työ elitististä, vain harvojen etuoikeus? Työnteon motiivit ovat moninaisia, mutta kirjoittajien mukaan ytimessä on halu edistää toisen hyvää, mikä vahvistaa merkityksellisyyden kokemusta. Johtajuus taas on parhaimmillaan merkitysten luomista, ylläpitämistä ja myötätuntoisen työyhteisön vaalimista.

\section{TUNTEET JA MYÖTÄTUNTO}

Synnymme osaksi laumaa, ja ihmisen perusluontoon sisältyy hyvän tahtominen ja oikeudenmukaisuuden vaaliminen. Siten on luonnollista, että haluamme tuntea yhteenkuulumisen ja turvallisuuden tunteita työelämässä.

Kirjoittajat kuvaavat myötätuntoa kolmiosaisena myötätuntotekona. Siihen kuuluvat kärsimyksen huomaaminen, empatian herääminen ja kärsimystä lievittävä teko. Määritelmä auttaa kuvaamaan myötätunnon syntymistä sekä sitä tukevia käytäntöjä ja sääntöjä.
Tunnetaidot, kyky myötäelämiseen ja myötätuntoon ovat tulevaisuudessa työelämän avaintaitoja. Työpaikoilla tunteet vaikuttavat muun muassa oppimiseen ja luovuuteen, päätöksentekoon, yhteistyöhön, terveyteen ja merkityksellisyyden kokemukseen.

Lukiessa vaikutuin eniten tutkimustuloksista, jotka kuvaavat hyvän tekemisen vaikutuksia hyväntekijään itseensä. Päivittäinen hyvä teko vahvistaa tyytyväisyyttä omaan elämään, aktivoi aivojen mielihyväalueita ja vähentää alttiutta sairastua masennukseen. Toivon, että kirja päätyy etenkin johtajien ja kouluttajien lukulistalle, sillä varsinkin heidän on syytä ymmärtää myötätunnon voima.

SANNA JUVONEN

$\mathrm{KM}$, lehtori

Laurea-ammattikorkeakoulu 